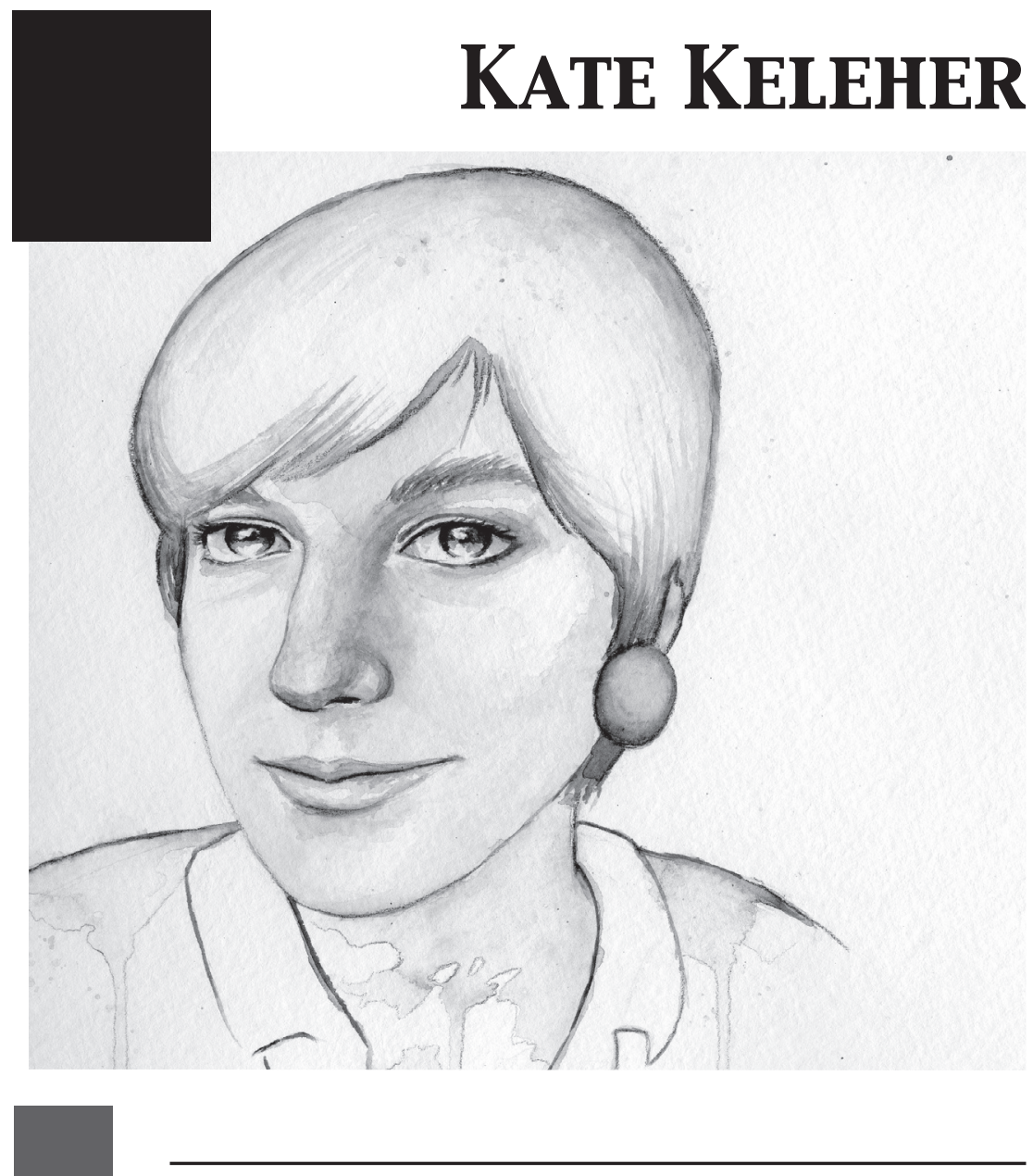

Kate Keleher of Winchester, MA, is a recent graduate of Macalester College with a degree in International Studies and minors in English and Environmental Studies. After backpacking across Southeast Asia for five months, she moved to Oakland, CA, where she spends her days cooking, dancing, making puns, and working at The Cheese School of San Francisco. 


\section{A SYCAMORE SINGS}

Mount Auburn Cemetery, that latticework of frayed nerves, curves to conceal us from the conversations of sidewalks and storefronts. Its paths unfurl slowly, in looping curls, which we follow quietly - the only way that two sore thumbs, one a few feet taller than the other, can respectfully rove among the eternally horizontal.

Of course, I don't know that. I am eight and still a child enough to hold my dad's hand and test the strange soles of his thumbs, split from claw hammer banjo. I twang:

"Whatcha want for your birthday?" To read his reply, I have to raise my earnest chin.

"Your boring old dad, he wants what he always wants: one cryptic haiku." Five, seven, five: the numbers above his initials on a telephone, the raw ingredients of his predictable passwords. Gold, green, gold: the color of his grandmother's name (Eva), Catholicism, frothy fields dyed by an automobile's mournful dirge.

"How'bout this one?" Withered stalks and husks encrust one stone. The crooked grave reads: Jack Straw, 1895 - 1957, Wichita.

He hems, "Wichita eh, how'd he get out here? You go first." This is our best game. I make a tale for the late Jack-be-nimble, but of course his is better, thanks to a thousand afternoon naps in front of prison movie reruns. Jumped the watchman, right outside the fence, took his rings, four bucks in change...

A plane splits the sky, slices the fabric of our game. The air is crisp, surprisingly so for September, and my apple-flesh lungs grapple with the chill to no avail.

No, there are no planes; it is September $14^{\text {th }}, 2001$. Three days earlier, my dad's old college roommate (one of two, both Irish, both named Brian), a priest at Saint Paul's Chapel, emerged safely; a sycamore in the chapel's courtyard shielded his two-hundred-forty-five-year-old church from falling debris. 
"Werntch'ya scared about Brian when those towers got hit?"

"Not really. I knew he'd be okay."

"How?"

"I just had a feeling." Hear the preacher and the baying of his hounds. The cemetery's tendrils pull us along. Rusted signs crusty with faded white lettering (Althea Way, Daphne Lane) punctuate the path; black bubbles cling to the branches of trees. We weave evenly, each trip rightward (hem) balanced at the fork with a turn back to the left (haw). Snot crusts on my green fleece sleeve. Too young to savor silence I continue in my quest to impress:

"Did'ya know, Dad, that people dream because their brains wanna use up all the extra information they take in during the day?"

"No, I did not." That paternal sing-song.

"It's true, I swear, I read it in Reader's Digest. That's why dreams predict the future sometimes. All that extra information we usually ignore is like little baby hints, y'know? And dreams turn it into scenes that actually happen." I raise my head to see his smug head bobbing, could be, could be, owl in a tree. Six foot seven, the leggy man. Dubbed Tree as a kid to distinguish him from the other three Roberts; together they formed The Four Bobbys, Malvern Elementary's singing quartet.

The path bows below a willow and an ice cream truck's tune (Pop Goes The Weasel) sours as it's pulled farther away. Ten years pass. Autumn. The black drains from my father's hair when his age exceeds that of Paul, his father, my unknown Pop (viewed in sepia tone only, through an upturned sherry glass of amber whiskey, shrouded in smoke). The second Bobby becomes a Barbara. In Kansas, Jack's daughter, dressed in blue, untangles a soggy scarlet begonia from her hair. Brian Shaughnessy stays put, worships that God. Brian Donnelly joins a cult in Florida, leaves after a year of oranges and weed, works for the post-office, adheres to conspiracy theories, fears The Man. The school bully gets pregnant at seventeen. My dad's Irish twins each divorce. Only his youngest sibling, sweet cleft-palated Patrick, left-handed, left-leaning, who cared for Lucy the dog after no one else would, finds love with an 
opera singer who looks just like him. Together they raise Eddy, a mentally challenged sixty year old with a flipper for an arm and a thing for blondes. I find my watch in the closet downstairs. My dad predicts all this.

The spiderless dream catcher holds only dust; my dad dreams not. All observed, there are no subtle details left to dream. He wakes at five every morning, the black stalks of hair on his neck froth frigid; he knows full well what is to come. A car shivers as it glides along the undulating landscape, cracks the ice from its spine. But some prophecies remain in crystal, uncracked:

Despite his nagging, why're you reading in the dark? I am not blind yet. 